\title{
A Note on Non-deterministic Turing Machine and the "P vs. NP ( P versus NP problem )"
}

\author{
杨正瓴 \\ 天津大学 电气自动化与信息工程学院 \\ 天津市南开区卫津路 92 号，邮编: 300072，中国 \\ Zheng-Ling YANG ( Zhengling Yang, Yang Zhengling) \\ School of Electrical and Information Engineering, Tianjin University \\ Weijin Road Campus: No. 92 Weijin Road, Nankai District, Tianjin, CHINA. Zip: 300072 \\ prai@tju.edu.cn \\ http://blog.sciencenet.cn/u/zlyang \\ 2021-04-12 试贴。
}

摘要：一个非确定型图灵机 NDTM 的计算过程，可以相当于其对应的确定型图灵机 DTM 的 幕集。如果接受 ZF 公理系统的幕集公理，“P 对 NP” 问题最可能的答案是：对于确定型图灵 机, $\mathrm{P} \neq \mathrm{NP}$ 。可以从另外 3 个角度对它进行一定的解释。

\begin{abstract}
The calculation process of a non-deterministic Turing machine (NDTM) can be equipotent to the power set of its corresponding deterministic Turing machine (DTM). If accepting the "Axiom of power set" of the ZF axiom system ( Zermelo-Fraenkel set theory ), the most likely answer to the "P vs. NP" ( $\mathrm{P}$ versus NP problem ) is: For a deterministic Turing machine, $\mathrm{P} \neq \mathrm{NP}$ ( $\mathrm{P}$ is not equal to NP). This answer can be explained from three other perspectives.
\end{abstract}

关键词：P 对 NP，非确定型图灵机，幕集公理，Zermelo-Fraenkel 集合论公理系统，确定 型图灵机, $\mathrm{P}$ 不等于 $\mathrm{NP}, \mathrm{P} \neq \mathrm{NP}$

KEY WORDS: P versus NP problem, non-deterministic Turing machine, Axiom of power set, Zermelo-Fraenkel set theory, deterministic Turing machine, $\mathrm{P}$ is not equal to NP, $\mathrm{P} \neq \mathrm{NP}$

数学证明有演绎和归纳两大类 ${ }^{[1]}$ 。对于演绎证明, 任何证明都是相对的, 因为该证明是 根据未被证明的前提得到的 ${ }^{[2]}$ 。The deduction and induction are two types of mathematical proofs ${ }^{[1]}$. For deductive proofs, any proof is relative, because the proof is based on certain unprovable assumptions ${ }^{[2]}$. 柴庭定理是一个更具体化的说明 ${ }^{[3]}$ 。Chaitin's theorems are some more specific explanations for the deductive proofs ${ }^{[3]}$.

对于 “P 对 NP” [4-12]，演绎证明可以得到三种不同的结论 ${ }^{[13-22]}$ : (1) 在非确定型图灵 机 NDTM 中，P等于 NP; (2) 在确定型图灵机 DTM 中，P 不等于 NP; (3) 没有关于所采用 的理论计算机模型的必要说明, 则具有独立性。For "P versus NP" ( P versus NP problem ) ${ }^{[4-12]}$, the deductive proofs can get three different conclusions [13-22]: (1) For a NDTM ( non-deterministic Turing machine ), $\mathrm{P}=\mathrm{NP}$ ( $\mathrm{P}$ is equal to NP); (2) For a DTM ( deterministic Turing machine ), $\mathrm{P} \neq \mathrm{NP}$ ( $\mathrm{P}$ is not equal to NP ); (3) If there is no necessary explanation about the theoretical computer models used, it is independent.

1. ZF 中的幕集公理和非确定型图灵机 “Axiom of power set” of the ZF axiom system ( Zermelo-Fraenkel set theory ) and the non-deterministic Turing machine 
The details can see "A non-canonical example to support that P is not equal to NP" ( Transactions of Tianjin University, 2011$)^{[19]}$ and “第二类计算机构想 Conception of the second class computer” (中国电子科学研究院学报, 2011, Journal of China Academy of Electronics and Information Technology, 2011$)^{[18]}$.

Encyclopedia of Mathematics has some related entries about the ZF ${ }^{[23,24]}$.

\section{2. “P 对 NP”另外 3 个角度的解释 Three other perspectives to explain the “P vs. NP ( P versus} NP problem )"

（1） “P 对 NP” 的核心是 “指数方式的增长”。从《图论》的角度看, 问题的图论模 型中包含非平面图 Kuratowski graphs $\left(K_{3,3}\right.$ and $\left.K_{5}\right)$ 是 “指数方式的增长”一个充分条件 ${ }^{[25-27]}$.

（2）在无穷化版本下, NPI（ NP-Intermediate）的存在性，就是“连续统假设 Continuum hypothesis” ${ }^{[28]}$ : 可数无穷基数 $a$ 和连续统基数 $c$ 之间是否存在一个其它的无穷基数。

(3) 概率意义下 ${ }^{[29]}$ 的 “对于 DTM, $\mathrm{P} \neq \mathrm{NP}$ ”, 即 “对于 DTM, $\mathrm{P} \neq \mathrm{NP}$ 几乎处处 ( almost everywhere, a. e. ) 成立。” 例如, 如果按照正态分布指定边 ( edge ) 的权重, 完全图( complete graph )上的 $\mathrm{TSP}^{[30]}$ 几乎处处需要指数时间。

\section{3. 从 “P 对 NP” 到 “第二类计算机” From "P vs. NP" to "the Second Class Computer"}

如果真的 “对于 DTM, $\mathrm{P} \neq \mathrm{NP}$ ”, 则应该研究能够 “将几何曲线作为整体处理” [31-33] 的计算机（第二类计算机）。

\section{参考文献 REFERENCES：}

[1] 中国大百科全书・数学 $[\mathrm{M}]$. 北京：中国大百科全书出版社, 1988 .

Encyclopaedia of China - Mathematics [M]. Beijing: Encyclopaedia of China Publishing House, 1988. (in Chinese)

[2] Proof [EB/OL]. A.S. Kuzichev (originator), Encyclopedia of Mathematics.

https://encyclopediaofmath.org/wiki/Proof

[3] CHAITIN G J. Information-theoretic computational complexity [J]. IEEE Transactions on Information Theory, 1974, 20(1): 10-15.

[4] COOK S. The P versus NP Problem, official problem description [EB/OL].

http://www.claymath.org/millennium/P vs NP/pvsnp.pdf

[5] ALLENDER E. A status report on the P Versus NP question [J]. Advances in Computers, 2009, 77: $117-147$.

[6] FORTNOW L. The Status of the P versus NP Problem [J]. Communications of the ACM, 2009, 52(9): 78-86.

[7] SIPSER M. The history and status of the P versus NP question [C]. Proceedings of the 24th Annual ACM Symposium on the theory of Computing' 92 (Canada), 1992: 603-618.

[8] COOK S. The importance of the P versus NP question [J]. Journal of the ACM, 2003, (50)1: 27-29.

[9] GAREY M R, JOHNSON D S. Computers and Intractability: A Guide to the Theory of NP-Completeness [M]. New York: W. H. Freeman, 1979.

[10] BAKER T, GILL J, SOLOVAY R. Relativizations of the $\mathrm{P}=$ ? NP question [J]. SIAM Journal on Computing, 1975, 4(4): 431-442.

[11] Juraj Hromkovic, Peter Rossmanith. What one has to know when attacking P vs. NP [J]. 
Journal of Computer and System Sciences, 2020, 107: 142-155.

[12] Jorge A. Ruiz-Vanoye, Ocotlán Díaz-Parra, Francisco Rafael Trejo-Macotela, Julio Cesar Ramos-Fernández. Editorial: P versus NP problem from Formal Languages Theory View [J]. International Journal of Combinatorial Optimization Problems and Informatics, 2021, 12(1): 1-8.

[13] 杨正瓴. 从 NP 结构到超级计算机分类理论 [R]. 天津大学百年校庆研究生院研究生学 术报告会 (一等奖论文), 和天津大学百年校庆自动化系学术报告会, 1995 年 10 月.

[14] 杨正瓴. 人脑有多复杂? [J]. 百科知识, 1997, 7 (总第 216 期) : 39-40.

[15] 杨正瓴. 人脑复杂性的估计及其哲学意义[M], 《中国新时期社会科学成果荟萃》, 1999, 第 1 卷 p296。卢继传 主编, 中国经济出版社, 北京, ISBN 7-5017-4100-X/G. 374, (第 2 编, 哲学, 第 4 章, 自然辩证法).

[16] 杨正瓴, 林孔元. 人类智能模拟的“第 2 类数学 (智能数学) ”方法的哲学研究 [J]. 哲 学研究, 1999, (4): 44-50.

[17] 杨正瓴. 密码学与非确定型图灵机 [J]. 中国电子科学研究院学报, 2008, 3(6): 558-562.

[18] 杨正瓴. 第二类计算机构想 [J]. 中国电子科学研究院学报, 2011, 6(4): 368-374.

[19] YANG Zhengling (杨正瓴). A non-canonical example to support that P is not equal to NP [J]. Transactions of Tianjin University, 2011, 17(6): 446-449.

[20] 杨正瓴, 2011-08-30, “P 对 NP”难题研究的形转换新思路 [EB/OL].

http://idea.cas.cn/viewdoc.action?docid=9402

[21] 杨正瓴, 2011-09-15, A FULL PROOF to the P versus NP problem [EB/OL].

http://blog.sciencenet.cn/blog-107667-486692.html

[22] 杨正瓴，2015-05-22, The kernel of "P vs NP Problem": Axiom of power set! [EB/OL].

http://blog.sciencenet.cn/blog-107667-892400.html

[23] ZFC [EB/OL]. Encyclopedia of Mathematics.

https://encyclopediaofmath.org/wiki/ZFC

[24] Axiomatic set theory [EB/OL]. Encyclopedia of Mathematics.

https://encyclopediaofmath.org/wiki/Axiomatic set theory

[25] Graph, planar [EB/OL]. Encyclopedia of Mathematics.

https://encyclopediaofmath.org/wiki/Graph,_planar

[26] Kuratowski graph [EB/OL]. Encyclopedia of Mathematics.

https://encyclopediaofmath.org/wiki/Kuratowski_graph

[27] Frank Harary. Graph Theory [M]. Reading, MA: Addison-Wesley, 1969.

[28] Continuum hypothesis [EB/OL]. Encyclopedia of Mathematics.

https://encyclopediaofmath.org/wiki/Continuum_hypothesis

[29] Normal distribution [EB/OL]. Encyclopedia of Mathematics.

https://encyclopediaofmath.org/wiki/Normal_distribution

[30] Travelling salesman problem [EB/OL]. Encyclopedia of Mathematics.

https://encyclopediaofmath.org/wiki/Travelling_salesman_problem

[31] Cantor theorem [EB/OL]. Encyclopedia of Mathematics.

https://encyclopediaofmath.org/wiki/Cantor_theorem

[32] KURATOWSKI K, MOSTOWSKI A. Set theory [M]. Amsterdam: North-Holland Publishing Company, 1976.

[33] SEIFE C. What are the limits of conventional computing? [J]. Science, 2005, 309(5731): 96. 